\title{
Soybean Production in Florida ${ }^{1}$
}

\author{
D. L. Wright, J. R. Rich, J. J. Marois, and R. K. Sprenkel ${ }^{2}$
}

Soybean acreage has been on the decline in Florida and the Southeast for a number of years due to low prices and low or stagnant yields stemming from periods of dry weather and lack of proper rotation. High yields are critical to being successful in growing soybeans. The 2002 farm bill may help growers decide whether soybeans are profitable and if it will fit into their farming operation. The previous farm bill did not encourage soybean production in the South and prices have fallen or remained unchanged over the last several years. Yearly updates to production costs can be found in Food and Resource Economics Department literature.

The biotechnology revolution with soybean began in 1995 and has been readily adopted by growers. Glyphosate resistant soybeans allowed growers more flexibility in timing of herbicide applications and has taken over more than $70 \%$ of the soybean acreage in the Southeast and nationally. This herbicide resistance has made the use of conservation tillage more dependable and economical with added benefits of timely planting, better stands, improved weed control and often better harvest conditions. Even with declining acreage, Florida and the Southeast continue to be a place where soybean can be grown economically if good rotation practices are followed and high yields are obtained.

\section{Land Preparation and Planting}

Conservation tillage planting of soybean was one of the first systems where no-till and strip till were used successfully all over the country. Soybeans are normally planted into a small grain cover crop or a crop harvested for grain and have been shown to be economical if the growing season is favorable for both crops. Most of the Coastal Plain soils have a natural compaction layer that limits root growth and thus the growth and yield of most crops. Subsoiling under the row to break the compaction layer with strip till equipment or high residue tillage implements such as the Para-till or Terra-Max has resulted in large yield increases that are especially noticed during dry years. If soybean is to be planted conventionally, in-row subsoiling after disk harrow preparation is still needed to break the compaction layer.

Burning the residue after small grain harvest prior to planting conventional tilled soybeans can result in stand damage by lesser corn stalk borers which may lead to replanting unless an insecticide is

1. This document is SS-AGR-182, one of a series of the Agronomy Department, Florida Cooperative Extension Service, Institute of Food and Agricultural Sciences, University of Florida. Original publication date September 2002. Visit the EDIS Web Site at http://edis.ifas.ufl.edu.

2. D. L. Wright, professor, J. R. Rich, professor, J. J. Marois, professor, and R. K. Sprenkel, professor, North Florida Research and Education Center-Marianna. Cooperative Extension Service, Institute of Food and Agricultural Sciences, University of Florida, Gainesville, Florida, 32611.

The use of trade names in this publication is solely for the purpose of providing specific information. UF/IFAS does not guarantee or warranty the products named, and references to them in this publication does not signify our approval to the exclusion of other products of suitable composition.

The Institute of Food and Agricultural Sciences (IFAS) is an Equal Employment Opportunity - Affirmative Action Employer authorized to provide research, educational information and other services only to individuals and institutions that function without regard to race, creed, color, religion, age, disability, sex, sexual orientation, marital status, national origin, political opinions or affiliations. For information on obtaining other extension publications, contact your county Cooperative Extension Service office. Florida Cooperative Extension Service / Institute of Food and Agricultural Sciences / University of Florida / Larry R. Arrington, Interim Dean 
used at planting. When planting into residue after small grain harvest, insects are seldom a problem.

Optimum planting dates for soybean range from Early May until mid June. However, soybean may be planted through July with narrow rows and irrigation. When planting in July, the height of plants is often limited; later-maturing varieties or juvenile soybeans should be planted, since these are not influenced as much by shorter day lengths and thus grow taller. Soybean varieties grown in the Southeast are placed in maturity Groups V-IX with the larger number indicating later maturity. In most years, Group V or early Group VI soybeans do well when planted after small grains in late May and June without irrigation. The reason for this is that rainfall tapers off at the end of August or by the middle of September. These earlier soybeans have a chance to fill pods during August and early September when Group VII and VIII soybean are still filling pods in late September and early October. Florida research shows that the optimum soybean yields can be made when planted in 36-inch rows during May and June without yield reduction. When planting in July, soybean should be planted in 10- to 20-inch rows to assure that the crop canopies cover the field. If soybeans form a full canopy by first bloom, yield limitations due to row spacing are minimal. If canopy closure does not happen at all or after first bloom, beans should be planted in more narrow rows. This not only affects yields but also means more expense for weed control and more moisture loss due to evaporation. Use of herbicide-resistant varieties make narrow row beans more feasible. Likewise, some of the herbicides have no residual activity, and the sooner the crop canopy forms, the sooner weeds will be shaded. If narrow rows are used, weeds have to be controlled by over-the-top herbicides prior to planting and some form of deep tillage is necessary to obtain top yields unless soybeans are irrigated. Stands on no-till-drilled soybeans are critical to success of the system. If soil conditions are hard, hot, and dry, seeds may not be placed at the proper depth for germination and growth. Small rainfall events may result in germination, but lack of moisture in the top few inches may result in stand loss. Strip-till planting is not as critical, since depth can be controlled and the subsoil slot often has adequate moisture for growth after germination.
Seeding rates vary with seed size. Research has shown almost no yield difference between 3 and 8 plants per row foot in 36 inch rows. When planting in 36-inch rows, planting 6-8 seeds per row foot amounts to about $35 \mathrm{lbs}$. of seed per acre. If a grain drill is used, 2-3 plants per foot are needed in 7- to 10-inch rows. This rate of seeding requires about 60 lbs. of seed per acre. Soybean seed should be planted from 1 to 1 1/2 inches deep in moist soil for best emergence.

\section{Fertilization}

Soybeans grown in rotation with well fertilized crops on the better soils in Florida seldom respond to direct fertilization. Data from soybeans inoculated with rhizobium (nitrogen fixing bacteria) showed no response to as much as $600 \mathrm{lbs}$. per acre of nitrogen $(\mathrm{N})$. Late $\mathrm{N}$ applications on irrigated soybeans during pod fill along with boron (B) applications gave a slight yield increase in some years. This may be due to a decline in root growth and $\mathrm{N}$ fixation as the soybean matures. Many soybean growers double crop with winter grazing or small grain for grain. Most or all of the phosphorus (P) and potassium (K) for both crops may be applied to the small grains crop on soils with a clay subsoil within the top 6-8 inches. Soils having a medium to high soil test level of $\mathrm{P}$ and $\mathrm{K}$ generally do not respond to direct fertilization in most years. Where soybeans are to be grown in a reduced tillage system, soil tests should be made at a more shallow depth to prevent the surface from becoming too acid, which may reduce herbicide effectiveness, especially if preemergence herbicides are to be used.

Soils are normally limed to a $\mathrm{pH}$ of 5.8-6.5 for soybean, and soil $\mathrm{pH}$ affects the availability of nutrients. Phosphorus is less available to plants at low and high $\mathrm{pH}$, while most micronutrients are less available to plants at a high $\mathrm{pH}$. In fields planted by conservation tillage methods, more frequent but smaller amounts of lime are necessary to keep the $\mathrm{pH}$ in the upper six inches at 5.8-6.5.

Research with boron in Florida has shown yield increases of 5-10\% when combined with Dimilin, an insecticide, late in the season. Solubor (a boron source) at 0.25 to $0.5 \mathrm{lb}$. per acre with a low rate of 
Dimilin at pod fill stage results in good season-long control of velvetbean caterpillar and a yield advantage.

\section{Managing Crop Residue}

Small grain harvested for grain leaves as much as two tons per acre of residue which could interfere with planting operations. In some cases straw may be baled and sold as road mulch or for other uses. Traditionally, producers burned straw when planting beans using conventional tillage methods. However, burning destroys most of the nitrogen in the small grain residue and reduces the potential for increased organic matter in the top couple of inches of soil. Burning also destroys the mulch effects of water conservation and temperature moderation as well as the effect of increasing the organic matter component of the soil as it decays. Burning straw has also attracted lesser corn stalk borer moths which have completely destroyed stands of beans. Where soybeans are strip tilled into wheat straw residue, stands are usually quick to establish. Modern strip till equipment and planters have little trouble with straw or old crop residue during planting. At one time, it was recommended to increase seeding rates by $10-15 \%$, but that is not necessary with new planters with row cleaners and better closing wheels.

If a no till drill is used to plant into wheat stubble, it should cut through the residue, penetrate the soil to the desired depth for proper seed placement and establish proper soil-to-seed contact. Small grains should be cut as high as possible to keep residue off the ground with a chopper or spreader to evenly distribute the residue. Stripper headers are available for combines that only take the grain leaving the standing plants. This aids in planting with drills. Extra weight can be added to no-till drills to cut through residue and to get better placement of seed. Heavy duty down-pressure springs help assure better seed placement. Closing wheels on drills should be set to help aid in good soil to seed contact. The key to increasing yields with no-tilling or strip tillage is having a heavy residue. Old crop residues seldom give the benefit of a well-managed cover crop. Long term benefits of planned cover crops include higher organic matter, better rooting depth, more nutrient and water holding capacity, better water infiltration, better stand establishment, less wind and water erosion, and many other factors.

\section{Irrigation}

Crops suffer through periods of drought each year in Florida. Much of our research shows that irrigated soybean yields of 55-65 bu/A are possible each year if other factors such as nematodes and fertility do not limit yields. Growers seldom put irrigation systems in for soybeans alone, but often do for rotation crops such as corn, cotton, and peanut. With soybean prices being in the $\$ 4-5$ per bushel range, little profit can be made even with high yields. Soybeans can be grown successfully after irrigated corn with yield potential of 40-45 bu/A if irrigation is applied as needed. Ownership or fixed cost must be paid whether the system is used or not. In most cases, the increases in yield will more than cover operating costs of the system. Generally, \$20-25/A will cover operating costs of irrigating soybeans, which means that an increase of about 5 bushels per acre would be needed. Yield increases of 15-35 bushes per acre could be expected in most years where irrigation is provided as needed.

Soybeans require little early irrigation except to get good plant height and provide canopy closure. Soybeans require the highest amount of water during late flowering through pod fill. Water use can be terminated when $50 \%$ of the soybean pods have beans touching in the pod and adequate soil moisture is available. Irrigation helps stabilize yields and makes for more dependable marketing strategies.

\section{Disease and Nematode Management}

Diseases have caused major losses to the soybean crop in Florida. Major diseases include stem canker, sudden death syndrome, and frogeye leaf spot. In some years, these diseases have caused yield losses of more than $\$ 300$ million across the south.

Seedling diseases can also cause stand losses in some years but plants compensate for a sparse stand throughout the growing season. Good rotation and careful attention to disease resistance of the varieties being grown is critical. Fungicide treated seed should 
be planted when tests indicate germination is less than $80 \%$, stand problems have been observed in fields in the past, wet soil conditions are expected when planting early or late, and when green stubble or residue is present in the seedbed.

Generally, stem canker occurs on susceptible varieties that are planted early. Susceptible varieties can be planted in June with less chance of stem canker occurrence. Later planting has also been shown to reduce the damage from sudden death syndrome and frogeye leaf spot. However, late planting can be a problem if irrigation is not available and dry weather occurs in September during pod fill. Stem canker can kill soybeans any time from mid-season to maturity. Dead plants with leaves still attached are an indication of its presence. Lesions at the base of the petiole on the stem are reddish brown. These lesions enlarge and spread until the stem is girdled and the part or the plant above the canker is damaged or killed. When split, infected stems may show a light brown discoloration of the vascular area with the pith turning chocolate brown. Yield losses can be from $50-100 \%$ in susceptible varieties when environmental conditions are favorable for the disease. Stem canker usually covers the entire field or area if susceptible varieties are planted and weather conditions are ideal for infection.

Sudden death syndrome (SDS) symptoms include interveinal chlorosis and necrosis. Leaves do not remain attached as with stem canker but fall prematurely leaving only the petiole attached. Lower stems and roots are discolored near maturity and the pith remains white. Lateral and tap roots are rotted at maturity, making plants easy to pull from the ground. SDS is found in fertile soils where moisture is abundant and soybean cyst nematodes are present. Yields of susceptible varieties can be reduced significantly with SDS affecting only parts of the field.

Frogeye leaf spot is usually much more severe on fields that have a history of wet soils or on flat wood soils. Control of this disease is by use of resistant varieties or recommended fungicides. Fields with a history of frogeye will normally have frogeye each year with significant yield loss. Frogeye leaf spot is a foliar disease but infection may occur on stems, pods, and seeds. After mid-season, small reddish brown spots appear on the upper leaf. As the lesions enlarge, they become gray, surrounded by a reddish brown halo. Yields are reduced when lesions are numerous and leaves wither and fall prematurely with yield losses as high as 50\%. Application of fungicide with boron and Dimilin has increased yields $10-15 \%$. Varietal resistance is the best defense to this disease as well as the other diseases.

Nematodes and disease may often go together as diseases are often a secondary infection resulting from damage to the root system. Soybeans are susceptible to many parasitic nematodes. Short rotations or rotating with crops susceptible to the same nematodes may increase nematode populations to damaging levels. Nematodes that attack soybean in Florida include root knot, reniform, and sting nematode. In addition, cyst nematode can reduce soybean yield but has no affect on other agronomic crops. The best defense to nematodes is varietal resistance and a good rotation. If nematodes are suspected, a soil sample should be collected immediately after harvest at the same time of soil sampling for nutrient analysis. This allows you to determine if nematodes are at an economically damaging level. Damage may also be determined by digging up soybean plants at harvest and looking at roots for root galls and pruned or decaying roots.

Generally, root knot and cyst nematode have done the most damage to soybean in Florida. There are several strains of cyst nematodes that may infect soybeans but only a few have been found in fields.

Nematicides are effective against nematodes but are expensive. Resistant varieties are on the market and should be used where known nematode problems exist and a plan for crop rotation to non-hosts such as bahiagrass should be considered. There are good economic programs showing the value of bahiagrass in rotation with row crops for reduction in nematode numbers as well as increasing yields from many unidentified factors. Information on control measures for nematodes in soybeans can be obtained at http://edis.ifas.ufl.edu/NG018.

\section{Variety Selection}

Variety selection should be based on factors including whether irrigation is available, nematodes 
are present, what kinds of diseases have occurred in the past, whether it is a single or double crop, and other considerations. Florida does not have a state variety test with soybean but information can be obtained from Georgia and Auburn locations close to locations across North Florida. The University of Georgia has a web site where this information can be obtained for Coastal Plain locations at http://www.griffin.peachnet.edu/swvt.

\section{Weed Control}

Weed control is a critical part of any crop produced in Florida. The success of a weed control program should be measured in terms of both weeds controlled and cost of the weed control program. Reduced rates of older less expensive herbicides, use of transgenic varieties, and reduced tillage are all keys to producing soybeans more economically. Proper rotations that allow use of different families of herbicides reduces the chance of weed resistance or tolerance being a problem. There is no herbicide that controls all weeds in all circumstances and therefore a plan for proper rotation and proper herbicides must be made on the weeds present in each field. Continuous use of a single family of herbicides is not advised as selection for specific uncontrolled weeds will occur. Yearly updates of "Weeds in the Sunshine" (http://edis.ifas.ufl.edu/WG010) provide a list of the herbicides labeled for soybean production in Florida, and effectiveness in controlling key weed species. For conservation tillage, cover crops and winter weeds must be controlled in a timely manner to avoid depleting the soil of moisture for planting and to prevent insect damage to seedlings. Normally, cover crops should be killed 3 to 4 weeks in advance of planting and should have accumulated close to 2 tons of dry matter for most benefits of water conservation and temperature moderation. Small grain cover crops often need an application of 2,4-D in January along with low amounts of $\mathrm{N}$ to kill many broadleaf winter weeds while stimulating the cover crop to produce enough biomass for the desired result. The cover crop is much easier to kill if broadleaf winter weeds are not present. Planting into green cover crops may mean limited moisture available to the planted crop as well as the possibility of damage from cutworm, wireworm and other insects that would not be present if the cover crop had been killed 3-4 weeks earlier.

\section{Insect Management}

Treatment for insects in soybean is an annual requirement, especially at pod-fill time. It is important to be able to identify which insects are present and the level of infestation. Early season insects that can cause problems including three cornered alfalfa leaf hoppers, lesser cornstalk borers, cutworms, and others. These insects normally cause the most damage when soybean plants are 10 inches tall or less. Stems are often girdled by the three-cornered alfalfa leaf hopper before damage is recognized. Their damage is usually noticed when plants begin to fall over from being girdled. Lesser cornstalk borer damage is usually recognized soon after planting by a reduction in stand. The damage is usually worse in sandy fields or in fields that have had the stubble burned prior to planting. Fields with a history of lesser cornstalk borers can be treated with materials like Lorsban $15 \mathrm{G}$ at planting in a 6-7 inch band incorporated into the top inch of soil. However, good rotation with a high residue crop may help alleviate this problem if the residue is not tilled in or irrigation will often solve the problem.

Cutworm populations are usually spotty but can cause significant damage on young seedlings. It occurs most often when high amounts of residue have been worked into the soil or when planting into a green cover crop that was not killed early enough. This damage will cease as plant stems get woody. Kill cover crops 3-4 weeks ahead of planting which will cause cutworms to die or leave since their food source is eliminated.

There are few insects that cause soybean plants a problem during the mid season. Armyworms can be a problem but seldom are. Worms are more likely to occur from late bloom to the end of pod fill. The rule of thumb in Florida is that $90 \%$ of the spraying on soybean is usually done during a two-week period on either side of Labor Day for worms, especially velvetbean caterpillar and corn earworm. Velvetbean caterpillars can destroy a stand of soybean plants in a period of 2 weeks but can easily be controlled with a low rate of Dimilin applied when soybean plants are 
near the end of the vegetative growth period or during the two week period around Labor Day. Other insecticides will normally be applied with Dimilin to control other worms as well as stink bugs which can be a problem during this period as well. Soybean loopers are foliage feeders as well and can contribute to defoliation. Corn earworms normally feed on the pods and can do a tremendous amount of damage to yield.

Stink bugs cause significant yield loss on many crops in the Southeast. Treatment should be triggered in soybean when one stink bug is found per foot of row. The southern green stink bug is usually the most numerous of the three types (southern green, southern, and brown). Stink bugs can cause a delay in maturity causing the green bean effect. These plants will remain green for a long period after normal defoliation if intensive stink bug damage occurred during the early to mid bloom period. This results in soybean being too green to harvest or will impart moisture to the soybeans resulting in a difficult harvest and high moisture beans. Soybeans require few insecticide treatments and seldom have more than a single application of insecticide. Late season stink bug control would require more than one application in most years.

Grasshoppers are sometimes found in soybeans after migrating from nearby field borders where weeds or grass are growing. Spot treatment may be needed where significant feeding is found. Latest insect control measures can be found in IFAS document ENY 405 (http://edis.ifas.ufl.edu/IG064), and in various industry and chemical handbooks.

\section{Harvesting and Storage}

Harvest losses for soybeans should be no more than 1 to 1.5 bushels per acre in a high yielding crop. There are many factors that can result in harvest losses. Below are listed ten steps to help minimize combine losses.

1. Harvest timely at dry down when soybeans are between 12-14\% moisture. This will prevent shattering losses that often occur when soybeans are less than $10 \%$ moisture.
2. The grain table or header of the combine should be level. Tire pressure should be the same on both sides and the tires should track in the row middles and not ride up on a bed. Tires should be kept out of furrows whenever possible to prevent the header from cutting through beans on the high side of the table or cutting above them. Floating grain tables are advantageous on uneven fields.

3. Keep grain tables or headers maintained. Keep cutter bars sharp and guards in good condition with hold-down clips and wear plates tight so the blade does not bounce around and shatter beans during the harvesting operation. All holes that occur in the platform and feeder house that could cause bean losses should be patched. All rough edges that might cause snagging or poor feeding should be eliminated so that cracking of beans from bunch feeding will not occur. Feed augers and feeder housing chains should be adjusted for a smooth feed. The slats on the feeder house chain should just touch the feeder housing floor. Augers or chains set too high will result in bunch feeding into the threshing cylinder or rotors.

4. Proper reel speed is very important in dry soybeans. High reel speeds can shatter beans before they reach the head. Reel speed should be about 1.25 times faster than ground speed to gently feed the crop into the head. The reel should "walk" through the crop resulting in a gentle pulling action to the top quarter of the plant. Short bean plants require the reel to be positioned further in front of the cutter bar. The same situation applies if there is an increase in ground speed.

5. More soybeans are lost to excessive ground speed than to most other factors. Ground speed should be determined by crop and ground conditions, header width, threshing capacity, and operator skill. Many older combines in Florida and the southeast do not have the threshing capacity of the newer machines, which can allow beans to ride out on plant material. Earlier research suggests an optimum ground speed of 2.8 miles per hour. However, with floating cutter bars and header height control, higher rates of travel can be utilized without significant losses. 
Some of the newer machines can travel at speeds up to $5 \mathrm{mph}$ with efficient harvests.

6. Make adjustments where needed to prevent bunch feeding, which is an indication that flow of plant material is uneven through the machine. This may be caused by excessive speed, the need for adjustments in feed augers or adjustments to other parts of the threshing mechanism. This is more important with rotary combines since they are more efficient when the rotor is fully loaded. Losses can be high when bunch feeding occurs. Piles of chaff behind the combine are a good indication of this as well as a surging engine.

7. Keep cylinder or rotor speed as low as possible to completely thresh the beans while keeping splits to a minimum. The drier the beans the slower the cylinder speed should be to keep bean damage to a minimum. Fine trash and broken beans in the grain tank is a good indication of too-fast cylinder speed.

8. Set the concave clearance as wide as possible to completely thresh the beans. A dry crop of soybean takes little threshing to remove beans from pods. Usually about a half inch clearance is needed for most soybeans under most conditions. Drier beans require less threshing, but more vigilance on beans coming into the grain tank is needed as field conditions change.

9. Fans should be adjusted to provide the right amount of air for separating the chaff from the beans. Too little air can result in more trash in the tank and beans walking out the sieves with the chaff, while too much air can blow the grain out of the combine.

10. Screen or sieve openings should be adjusted along with air adjustment to allow grain to pass through the screens while keeping the chaff from falling through, which results in trashy grain and consequently results in discounts from high moisture.

There are four main areas to inspect when checking for proper threshing adjustments:
1. ground losses;

2. tailings conditions;

3. samples of grain in the grain tank;

4. shoe sieve materials.

An operator totally familiar with the operation and adjustments of a combine can make the difference between losses of 1 versus 4 bushels per acre or more. If a machine can harvest 4 acres per hour, this could result in savings of $\$ 50$ per hour. It is important to teach each operator required techniques on machine operation and adjustments under changing conditions.

On-farm storage has been done as part of marketing options as well as allowing soybeans to be harvested faster when grain elevators could not handle the volume. On-farm stored soybeans must have some means of circulating air through them. If soybeans are $15 \%$ moisture or higher, supplemental heat may be required to accomplish adequate drying. The safest moisture content for bin storage is around $10 \%$ at temperatures of $60^{\circ} \mathrm{F}$. Air should be blown through beans on dry afternoons occasionally to prevent high moisture areas that can result in hot spots and spoilage of beans. Do not aerate when humidity is high or during rainy periods.

Storing soybeans for seed requires much more quality control of both aeration and heat in drying to maintain good germination and quality. For special assistance in seed storage, consult your county Extension Agent. 